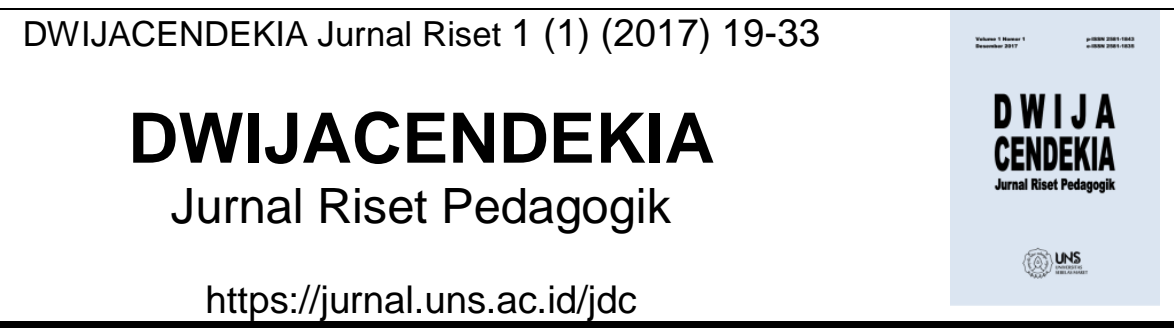

\title{
ANALISIS LEARNING TRAJECTORY MATEMATIS DALAM KONSEP PERKALIAN BILANGAN CACAH DI KELAS RENDAH SEKOLAH DASAR
}

\section{Ejen Jenal Mutaqin}

\section{STKIP Garut}

\section{Sejarah Artikel}

Diterima 11 Juli 2017

Disetujui 19 Juli 2017

Diterbitkan 1 Agustus 2017

\section{Kata Kunci}

Learning Tarajectory,

Perkalian Bilangan Cacah,

Siswa Kelas Rendah

Sekolah Dasar

\begin{abstract}
Abstrak
Strategi atau cara siswa kelas rendah sekolah dasar dalam melakukan perkalian cukup variatif. Hal ini mendorong peneliti untuk mengkaji lebih jauh tentang Learning Trajectory perkalian siswa kelas rendah sekolah dasar melalui penelitian. Fokus penelitian ini adalah berusaha mengungkap pola empirical learning trajectory konsep perkalian di kelas rendah sekolah dasar. Penelitian ini menggunakan pendekatan kualitatif dengan metode studi kasus dimana subjeknya adalah siswa kelas rendah sekolah dasar. Berdasarkan hasil penelitian disimpulkan (1) Secara umum terdapat lima pola empirical learning trajectory perkalian bilangan cacah di kelas rendah sekolah dasar yaitu: pemodelan dengan benda konkret, pemodelan dengan gambar, penjumlahan, raraban, dan pola buku teks BSE. Hypothetical learning trajectory perkalian dapat disusun berdasarkan pola empirical learning trajectory sehingga dapat digunakan guru sebagai petunjuk dalam membagi tahapan pembelajaran dan dapat memberikan berbagai alternatif strategi ataupun scaffolding untuk membantu dan mengatasi siswa yang mengalami kesulitan dalam memahami konsep perkalian bilangan cacah di kelas rendah sekolah dasar.
\end{abstract}

\section{Cara Mengutip}

Mutaqin, E.J. (2017). Analisis Learning Trajectory Matematis dalam Konsep Perkalian Bilangan Cacah di Kelas Rendah Sekolah Dasar. DWIJACENDEKIA Jurnal Riset Pedagogik, 1(1), 19-33. 


\section{PENDAHULUAN}

Mata pelajaran matematika yang penuh dengan perhitungan ini dicap oleh sebagian orang sebagai pelajaran yang sulit dan menyulitkan. Saleh (2009) menyebutkan salah satu faktor yang menyebabkan pelajaran matematika tampak sulit karena banyaknya perhitungan yang melibatkan angka dan logika. Perkalian termasuk salah satu topik dalam matematika di sekolah dasar yang sulit dipahami oleh sebagian siswa.

Perkalian merupakan kompetensi operasi bilangan yang mulai diperkenalkan kepada siswa kelas dua semester kedua. Kompetensi tersebut sebagaimana diamanatkan dalam Standar Isi Sekolah Dasar/Madrasah Ibtidaiyah tentang Standar Kompetensi yaitu "Melakukan perkalian dan pembagian bilangan sampai dua angka" dan Kompetensi Dasar yaitu "Melakukan perkalian bilangan yang hasilnya bilangan dua angka" (Depdiknas, 2006).

Berdasarkan hasil observasi dan wawancara dengan guru mengenai hasil evaluasi yang dilakukan oleh guru kepada siswa kelas rendah, ternyata dalam mengerjakan soal perkalian tersebut ada yang cepat, ada yang lambat, ada yang masih kesulitan, dan bahkan ada juga siswa yang masih keliru dalam memahami konsep perkalian. Misalnya saja, ketika siswa diperintahkan untuk menyelesaikan soal "Ada tujuh kotak berisi kue. Setiap kotak berisi tiga buah Kue. Berapakah banyak kue seluruhnya?...".

Dalam menyelesaikan soal tersebut, beberapa siswa menggunakan cara terbaiknya dengan menggunakan alat bantu hitung sebagai model: siswa menggambar 7 buah kotak yang berisi 3 bulatan kecil dalam setiap kotaknya, kemudian membilang satu-satu $(1,2$, $3,4,5,6,7,8,9,10,11,12,13,14$, $15,16,17,18,19,20,21)$, Ada juga yang membilang tiga-tiga $(3,6,9,12$, $15,18,21$ ) sehingga didapat jawaban banyaknya bulatan-bulatan kecil dalam seluruh kotak tersebut adalah 21 . Seperti pada gambar dibawah ini:

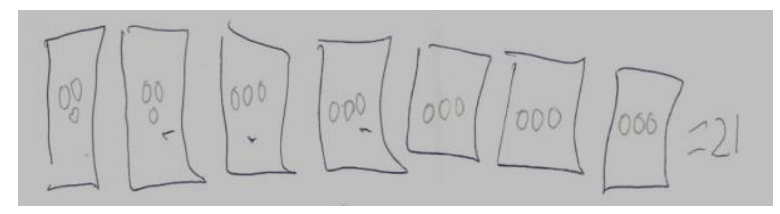

Gambar 1. Jawaban Siswa 1

Dari gambar diatas, beberapa siswa melihat itu sebagai $3+3+3+3+3+3+3=21$. Selanjutnya, siswa lain yang telah akrab dengan perkalian, menjawab soal tersebut dengan $7 \times 3=21$.Pada kasus yang lain, ketika siswa diperintahkan untuk menyelesaikan sebuah kalimat perkalian ... X ... $=28$, umumnya siswa dapat menjawab pertanyaan tersebut dengan benar yaitu $4 \times 7=28,7 \times 4=28$, $1 \times 28=28, \quad 2 \times 14=28$. Tetapi, ketika diperintahkan untuk menggambarkan operasi perkalian $4 \times 7=28$ siswa menjawab seperti pada gambar dibawah ini:

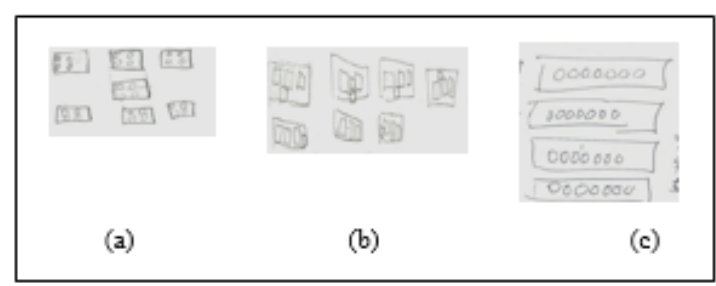

Gambar 2. Jawäban Siswa 2

Strategi-strategi atau cara-cara siswa tersebut merupakan salah satu tahap dari learning trajectory. Menurut 
Simon 1995 learning trajectory merupakan lintasan atau rute belajar yang memberikan gambaran tentang pengetahuan prasyarat yang telah dimiliki siswa (sebagai titik start) dan setiap langkah dari satu titik ke titik berikutnya, menggambarkan proses berpikir dan metote yang siswa gunakan, ataupun tingkat-tingkat berpikir yang siswa tunjukkan.Mengingat pentingnya pendidikan yang berkesinambungan dari sisi konten dan proses, Mathematical Learning Trajectory menjadi isu penting dalam pembelajaran matematika. Untuk itu, sebagai praktisi bidang pendidikan dasar penulis tertarik untuk lebih jauh mengamati learning trajectory dalam proses penelitian. Proses ini berusaha mengungkap arah dan pola lintasan belajar perkalian. Dari pola tersebut kemungkinan ada cara yang efektif untuk mendukung kompetensi matematis berikutnya.

Penelitian ini sekaligus menjawab kebutuhan dalam studi matematika tentang upaya yang dapat menstimulasi para siswa untuk membangun dari pengalamanpengalaman individual dan mengembangkan kemampuan siswa untuk berpikir matematis. (Wahyudin, 2010). Selain itu, guru dapat mempertimbangkan keragaman respon siswa atas situasi didaktis yang dikembangkan sehingga rangkaian situasi didaktis yang dikembangkan berikutnya sesuai dengan keragaman lintasan belajar (learning trajectory) masing-masing siswa (Suryadi, 2011).

$\mathrm{Di}$ kelas rendah sekolah dasar pembelajaran perkalian bilangan cacah dipilah menjadi dua tahap, yaitu perkalian dasar (perkalian satu digit) dan perkalian lanjut (perkalian multi digit).Ketika anak belajar perkalian baik perkalian dasar maupun perkalian lanjut, mereka mengikuti suatu pola tingkatan alamiah, yakni belajar kemampuan-kemampuan dan ide-ide konsep perkalian dengan cara mereka sendiri. Setiap anak memiliki alur yang berbeda untuk sampai pada konsep perkalian bilangan cacah, baik dalam perkalian dasar maupun perkalian lanjut. Oleh karena itu, maka yang menjadi fokus dalam penelitian ini adalah "Bagaimana pola empirical learning trajectory perkalian bilangan cacah di kelas rendah sekolah dasar?"

\section{METODE PENELITIAN}

Penelitian dilaksanakan di SDN Karangmulya 02 Subjek dalam penelitian ini adalah siswa kelas rendah sekolah dasar mulai dari kelas 1 sampai kelas 3. Pemilihan siswa yang menjadi sumber data dilakukan menggunakan purposive sampling. Penelitian ini menggunakan pendekatan kualitatif karena penelitian ini berusaha mengeksplorasi secara mendalam tentang fenomena sentral learning trajectory perkalian bilangan cacah siswa kelas rendah sekolah dasar. Sedangkan metode yang dipilih adalah metode studi kasus dimana pada penelitian ini berusaha mengungkap pola empirical learning trajectory perkalian. Untuk memperjelas tahapannya maka peneliti mencoba melukiskan dalam bagan alur penelitian sebagai berikut: 


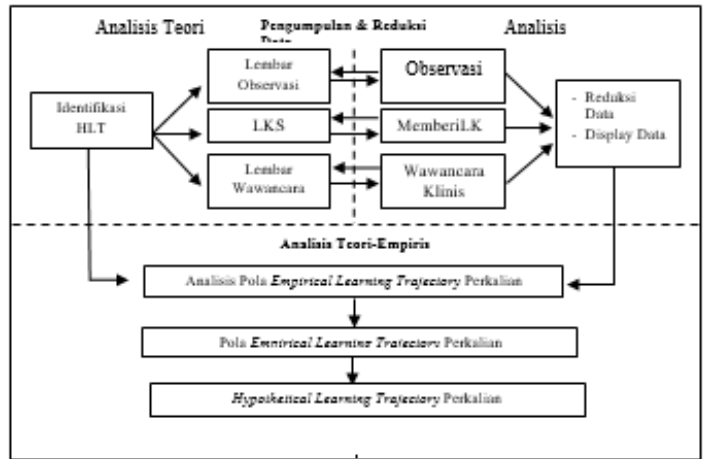

Gambar 3.Bagan Alur Penelitian

Instrumen yang digunakan dalam penelitian ini adalah lembar studi dokumen RPP, Lembar wawancara tentang hypothetical learning trajectory, LKS dan Lembar Wawancara Klinis. Secara umum, ada dua analisis yang dilakukan: (1) analisis hypothetical learning trajectory berdasarkan data identifikasi HLT; (2) analisis pola empirical learning trajectory berdasarkan data hasil LKS dan Wawancara Klinisnya. Data hasil analisis berupa arah dan pola empirical learning trajectory tersebut kemudian dikaji hubungan antar kelompok, kemudian dikaji pula hubungan dengan literatur. Bahkan jika memungkinkan bisa menentukan learning trajectory perkalian yang efektif untuk kompetensi berikutnya.

\section{PEMBAHASAN}

Salah satu teori belajar matematika yang berpengaruh adalah teori dari Jean Piaget, seorang psikolog terkenal dari Swiss (Wahyudin, 2012:80). Teori Piaget menjelaskan cara orang berfikir, memahami dan belajar. Piaget meyakini bahwa kecerdasan adalah proses kognitif atau mental yang yang digunakan oleh anak untuk memperoleh pengetahuan. Anak-anak mengikuti suatu pola tingkatan alamiah ketika mereka belajar maupun dalam proses perkembangannya. Sebagai contoh, anak-anak mengalami pola yang sama pada perkembangan mereka dari belajar tengkureb, merangkak, berdiri, berjalan, lalu berlari, dan melompat dengan kecepatan dan kecekatan yang terus meningkat seiring dengan perkembangan fisiknya.

Sama halnya dalam proses belajar mereka. Strategi atau cara para siswa menuju situasi belajar dan penalaran mereka sangat variatif. M. Suzanne
Donovan dan John D. Bransford (2005) dalam bukunya How Students Learn History, Mathematics, and Science In The Classroom menggambarkan ada berbagai alur atau proses berpikir (learning trajectory) anak yang berbeda dalam memahami matematika. Istilah learning trajectory (alur belajar) pertama kali digunakan oleh Simon (1995:136) yang mengajukan konsep tentang hypothetical learning trajectory Learning trajectory yaitulintasan atau rute belajar yang memberikan gambaran tentang pengetahuan prasyarat yang telah dimiliki siswa (sebagai titik start) dan setiap langkah dari satu titik ke titik berikutnya, menggambarkan proses berpikir yang siswa gunakan, metode yang siswa pakai, ataupun tingkattingkat berpikir yang siswa tunjukkan.

Salah satu konsep matematika yang dipelajari di sekolah dasar adalah perkalian. Taylor dan Mills (1961:69) mendefinisikan "Multiplication is the 
shortened process of finding the sum of equal addends by using the addition facts". Perkalian sebagai proses pendek untuk menemukan jumlah dari bilangan-bilangan yang sama pada setiap sukunya melalui penggunaan fakta-fakta penjumlahan.. Pada prinsipnya perkalian sama dengan penjumlahan bilangan cacah secara berulang, dimanabilangan cacah merupakan bilangan-bilangan kardinal dari himpunan-himpunan yang terhingga atau bilangan $0,1,2$, $3,4,5$, dan seterusnya (Wahyudin, 2010). Oleh karena itu, prasyarat yang harus dimiliki siswa sebelum mempelajari perkalian adalah penguasaan konsep bilangan,penjumlahan bilangan cacah, dan nilai tempat bilangan. (Heruman, 2007:22).

Di sekolah dasar pembelajaran perkalian dipilah menjadi 2 (dua) tahap, yaitu perkalian dasar dan perkalian lanjut.Perkalian dasar adalah perkalian dari dua bilangan yang masing-masing terdiri dari satu angka (Marsudi Raharjo dkk, 2009:51), seperti perkalian $2 \times 3=6$, $6 \times 7=42, \quad 3 \times 8=24$ dan sebagainya. Sedangkan Perkalian lanjut adalah perkalian yang melibatkan dua bilangan selain dua bilangan satu angka (Marsudi Raharjo dkk, 2009:51).. Artinya perkalian dari dua bilangan dengan salah satu bilangannya lebih dari satu angka atau kedua-duanya lebih dari satu angka atau multi digit, seperti $7 \times 66=462, \quad 6 \times 123=738$, $9 \times 5250=47250, \quad 16 \times 25=400, \quad$ dan seterusnya.

Ketika siswa belajar perkalian baik perkalian dasar maupun perkalian lanjut, mereka mengikuti suatu pola tingkatan alamiah, yakni belajar kemampuan-kemampuan dan ide-ide perkalian dengan cara mereka sendiri. Secara umum pola learning trajectory perkalian yang terungkap ada enam tipe yaitu:

\section{Pola pemodelan dengan benda konkret}

Cara berfikir anak dalam menyelesaikan soal yang diberikan pada pola ini cenderung berpikir semi konseptual (Zuhri,1998) dimana cara berpikir anak dalam memecahkan masalah menggunakan konsep atau skema yang telah dia miliki berdasarkan hasil pelajaran yang pernah dialami tetapi mungkin karena pemahamannya terhadap konsep tersebut belum sepenuhnya lengkap maka penyelesaiannya dicampur dengan cara penyelesaian yang menggunakan instuisi.

Dalam pola ini siswa cenderung menggunakan benda konkrit dalam menyelesaikan masalah yang diberikan. Kemudian dilanjutkan dengan membilang satu-satu. Pola membilang satu-satu dilakukan oleh beberapa siswa dan dilakukan dengan menggunakan benda konkrit. Membilang satu-satu melibatkan aktivitas membilang menaik dimulai dari satu sampai bilangan terakhir yang diucapkan. Hasil dari pola ini adalah pembilangan terakhir yang diucapkan merupakan jumlah dari semua bilangan yang dibilang. Artinya siswa tersebut sudah mampu membilang dengan benar (rational counting) dimanasiswa sudah bisa menyebutkan jumlah bilangan sesuai dengan hasil membilang yang dilakukannya. Kemampuan membilang secara rasional merupakan keterampilan yang sangat penting untuk anak usia sekolah dasar. (Herman, 1999). Ketika siswa membilang banyak benda seperti 
banyaknya permen, atau manikmanik, maka siswa mengambil bendabenda tersebut untuk dibilang berapa banyak benda seluruhnya. Karakteristik permen, biji jagung, atau kalung manik-manik adalah konkret dan mudah dioperasikan sehingga siswa tidak mengalami masalah berarti dalam membilang benda dengan menggunakan permen atau kalung manik-manik. Sebagaimana dijelaskan Piaget (Wahyudin, 2010) bahwa untuk meningkatkan perkembangan mental anak ke arah yang lebih tinggi dapat dilakukan dengan memperkaya pengalaman anak melalui pengalaman konkret, karena dasar perkembangan mental anak melalui pengalamanpengalaman aktif melalui bendabenda konkret yang ada di sekitar anak.

Satu hal yang perlu diperhatikan ketika anak membilang sampai pada bilangan yang dinyatakan dengan dua digit atau lebih seperti sepuluh (10), dua belas (12), dua puluh satu (21), seratus (100), dua ratus tiga puluh satu (231) seribu (1000), dua ribu lima ratus tujuh puluh enam (2576), Pertanyaan seperti "kenapa angka 12 dibaca dua belas bukan satu dua?", atau "152 dibaca seratus lima puluh dua bukan satu lima dua?.”. Dari sini merupakan sarana yang efektif untuk memfasilitasi anak untuk mengingatkan kembali konsep nilai tempat (satuan, puluhan, ratusan, ribuan). Wahyudin (2010) menyatakan bahwa konsep nilai tempat dapat menjadi sangat abstrak tetapi merupakan konsep yang sangat penting sehingga harus dibangun dengan baik.

Untuk memberikan pemahaman konsep nilai tempat kepada anak, dapat dilakukan dengan memberikan banyak pengalaman dalam pengelompokan benda-benda hitung seperti dua belas buah permen kedalam kelompok satuan dan puluhan. 12 dapat dinyatakan dengan sepuluh buah permen yang dibungkus menjadi satu kemudian dimasukan kedalam satu kantong plastik puluhan dan dua buah permen yang dimasukan kedalam kantong plastik satuan. Plastik transparan dapat dimanfaatkan sebagai media pemahaman konsep nilai tempat. Perbedaan harus dibuat antara sepuluh kelompok yang terdiri dari satu anggota dan satu kelompok yang terdiri dari sepuluh anggota, sehingga anak menyadari bahwa tidak lebih dari sembilan biji hitung boleh ditempatkan di tempat satuan. Misalnya, menentukan mana yang termasuk nilai tempat puluhan dan mana yang menempati nilai satuan, seperti pada gambar berikut ini:

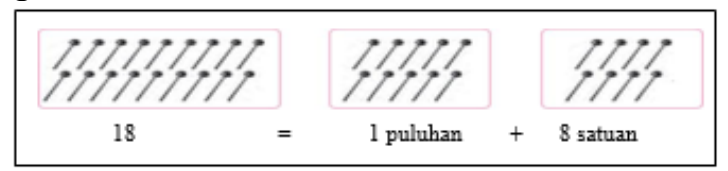

Gambar 4. Contoh Penyajian Nilai Tempat Bilangan dengan Batang Korek Api

Keadaan ini sesuai dengan teori Piaget bahwa anak-anak dapat menampilkan pikiran logis, dimana anak memahami konservasi dan proses logis lainnya dengan memanipulasi obyek (Wahyudin, 2012). Dengan kata lain, pada pola ini merupakan permulaan berpikir rasional. Ini berarti anak memiliki operasi-operasi logis yang dapat diterapkannya pada masalah-masalah yang konkret.

Oleh karena itu, aktivitas belajar anak akan melalui tahap skema, adaptasi, disequilibrium dan equilibrium 
(Haryanto; Harahap; Dahar, 2006). Menurut Piaget, setiap anak memiliki struktur kognitif yang disebut skema atau schemata yaitu sistem konsep yang ada dalam pikiran sebagai hasil pemahaman terhadap objek yang ada dalam lingkungannya. Pemahaman tentang objek tersebut berlangsung melalui proses adaptasi yaitu kecenderungan untuk menyesuaikan diri atau beradaptasi dengan lingkungan mereka (Dahar, 2006; Harahap). Pada tahap ini terdapat dua proses kognitif yang saling terkait yaitu asimilasiterjadi ketika anak memasukan informasi baru ke dalam skema mereka yang sudah ada sebelumnya, dan akomodasi terjadi ketika anak menyesuaikan skema mereka agar sesuai dengan informasi atau pengalaman baru mereka. Menurut Piaget (Suparno, 2001) unsur paling penting dalam perkembangan pemikiran seorang anak adalah ekuilibrium. Ekuilibrium merupakan mekanisme internal yang diajukan untuk menjelaskan bagaimana anakanak beralih dari satu tahap pemikiran ke tahap pemikiran berikutnya. Peralihan ini terjadi ketika anak-anak mengalami konflik kognitif atau ketidakseimbangan (disequilibrium) dalammemahami sesuatu. Konflik kognitif inilah yang dapat menantang anak untuk terus melakukan asimilasi dan akomodasi terhadap skema awal yang dimiliki oleh anak. Kalau sudah sampai pada keseimbangan lagi, proses dapat diulang lebih lanjut dengan pengajuan masalah yang dapat memfasilitasi kegiatan "konstruktif" dan dalam rangka terciptanya "disequilibrium" serta penciptaan "konflik kognitif" sehingga pembentukan skema baru tentang konsep perkalian lebih bermakna.

Dengan cara seperti itu secara bertahap anak dapat membangun pengetahuan melalui interaksi dengan lingkungannya.

Sebagaimana dikemukakan oleh Vygotsky (Dahar, 2006) bahwa orang dewasa (guru) sangat berperan dalam membantu anak belajar dengan menunjukkan benda-benda atau dengan mengajukan pertanyaan. Dengan kata lain, orang dewasa menjadi perantara bagi anak dan dunia sekitarnya. Untuk mengatasi anak yang mengalami kesulitan ketika menyelesaikan permasalahan yang diberikan, orang dewasa (guru) dapat memberikan petunjuk dengan mengajukan pertanyaan atau memberikan penjelasan tambahan sehingga anak yang mengalami kesulitan dapat melanjutkan pada tingkat masalah yang baru.

\section{Pola pemodelan dengan gambar} Cara berfikir anak dalam menyelesaikan soal yang diberikan pada pola ini cenderung berpikir semi konseptual (Zuhri,1998), akan tetapi pada pola siswa sudah bisa membawa hal-hal yang konkrit menjadi semi-abstrak, dimana siswa sudah mampu mengandaikan bahwa gambar tersebut bisa mewakili benda nyata. Artinya dalam pola ini sejalan dengan teori Brunner (dalam Hudoyo, 1990) bahwa siswa sudah mampu menemukan keteraturan dengan cara mengotak-atik bahan-bahan yang berhubungan dengan keteraturan intuitif yang sudah dimiliki siswa.

Dalam pola ini siswa cenderung menggunakan skema yang telah dimilikinya berupa prosedur-prosedur penyelesaian soal dan merepresentasikan soal ke dalam bentuk gambar, artinya anak sudah tidak terlalu bergantung pada benda konkret. Pada tahap ini anak merepresentasikan soal menjadi sebuah gambar, kemudian 
melanjutkan dengan membilang satusatu. Membilang satu-satu melibatkan aktivitas membilang menaik dimulai dari satu sampai bilangan terakhir yang diucapkan. Hasil dari pola ini adalah pembilangan terakhir yang diucapkan merupakan jumlah dari semua bilangan yang dibilang. Artinya siswa tersebut sudah mampu membilang dengan benar (rational counting) dimanasiswa sudah bisa menyebutkan jumlah bilangan sesuai dengan hasil membilang yang dilakukannya. Kemampuan membilang secara rasional merupakan keterampilan yang sangat penting untuk anak usia sekolah dasar. (Herman, 1999). Ketika siswa membilang maka siswa gambar yang mewakili benda konkrit tersebut untuk dibilang berapa banyak benda seluruhnya.

Selanjutnya, siswa diarahkan untuk mencari cara lain sampai terungkap dengan melihat kumpulan-kumpulan yang ada pada gambar, selanjutnya siswa menuliskan lambang bilangan dan operasi penjumlahan, kemudian menjumlahkan bilangan-bilangan tersebut sampai diketahui jumlah seluruhnya. Dalam aktivitas menjumlahkan, beberapa siswa melakukan membilang melanjutkan (counting on) dimana pada proses menjumlahkan dan setelah diketahui hasil yang sebelumnya siswa melanjutkan membilang untuk mengetahui hasil yang selanjutnya dengan membilang menggunakan jari tangannya.

Dalam aktivitas belajar belajar siswa harus terlibat aktif mentalnya agar dapat mengenal konsep dan struktur yang tercakup dalam bahan yang sedang dibicarakan, dan anak akan memahami konsep yang harus dikuasainya itu. Ini menunjukkan bahwa konsep yang mempunyai suatu pola atau struktur tertentu yang akan lebih mudah dipahami dan diingat anak. Oleh karena itu, pembelajaran konsep perkalian hendaknya dimulai dengan pengenalan masalah yang sesuai dengan situasi yang ada disekitar siswa (contextual problem). Dengan mengajukan masalah kontekstual, peserta didik secara bertahap dibimbing untuk menguasai konsep perkalian.

\section{Pola penjumlahan}

Dalam pola ini siswa cenderung menggunakan skema yang telah dimilikinya berupa prosedur-prosedur penyelesaian soal perkalian. Cara berfikir anak dalam menyelesaikan soal yang diberikan pada pola ini cenderung berpikir konseptual dimana cara berpikir anak dalam memecahkan masalah menggunakan konsep yang telah dia miliki berdasarkan hasil pembelajaran yang telah dialaminya, adapun indikator cara berfikir koseptual, yaitu dimana (1) anak mampu mengungkapkan dengan kalimat sendiri apa yang diketahui dan ditanya dalam soal, (2) anak mampu menghubungkan konsep yang telah dipelajari terhadap apa yang ditanya dalam soal (3) dalam menjawab cenderung menggunakan konsep yang telah dipelajari (4) sudah dapat menjelaskan langkah-langkah dalam pemecahan masalah (Zuhri,1998).

Pola ini terdiri atas aktivitas menjumlahkan bilangan yang sama secara bersusun sampai diperoleh bilangan baru sebagai hasil dari penjumlahan bilangan seluruhnya. Selanjutnya, untuk mengarahkan siswa memahami konsep perkalian dapat mengajukan pertanyaan- 
pertanyan seperti: "Apakah ada cara lain untuk menjumlahkan b sebanyak a kali?"..Berapa kali kamu menjumlahkan b sampai kamu tahu hasilnya $c$ ? Sampai siswa memahami konsep perkalian dasar dengan benar dimana ketika siswa melihat bentuk penjumlahan " $b+b+b+b$ sebanyak $a$ kali" sama dengan $a x b=c$ atau sebaliknya ketika siswa menjumlah a sebanyak b kali, maka itu sama dengan bxa=c (Wahyudin, 2010).

Sebagaimana teori Piaget (dalam Haryanto; Harahap; Dahar, 2006) aktivitas belajar anak dalam pola ini akan melalui tahap skema, adaptasi, disequilibrium dan equilibrium. Pada pola ini, anak cenderung menggunakan skema awal, kemudian beradaptasi dengan asimilasi, kemudian terjadi equilibrium untuk membentuk skema baru.

\section{Pola raraban}

Raraban adalah catatan hapalan perkalian dasar (perkalian satu sampai dengan sepuluh). Ketika siswa menemukan soal perkalian siswa langsung melihat angka-angka yang ada di dalam soal kemudian mengalikannya, seperti ketika siswa melihat ada angka 3 dan 6 didalam soal, tanpa berfikir lama langsung menjawab bahwa itu $3 \times 6$ padahal yang dimaksud didalam soal itu sebagai bentuk $6 \times 3$. Cara berfikir yang seperti ini, Zuhri (1998) menyebutnya sebagai berpikir komputasional dimana cara berpikir yang pada umumnya menyelesaikan suatu masalah tidak menggunakan konsep yang telah dipelajari. Siswa dapat menjawab soal karena dia hapal bukan karena dia paham (rote memorization) yaitu proses menghapal informasi atau kaidahkaidah tanpa suatu pemahaman prinsip atau makna yang terkandung di dalam informasi atau kaidah itu (Wahyudin, 2012:100). Herman dalam artikelnya menyatakan bahwa jika tanpa pemahaman konsep, siswa akan kesulitan dalam mengikuti perkembangan matematika, juga dalam menyelesaikan permasalahanpermasalahan yang sering dijumpai dalam kehidupan sehari-hari.

Untuk mengatasi hal itu, ketika memperkenalkan perkalian di kelas dua jangan langsung mendorong anak-anak untuk menghapalkan faktafakta perkalian dasar (Wahyudin, 2010:27). Agar pembelajaran perkalian menjadi lebih bermakna dan dapat memberikan kecakapan hidup, sebaiknya pembelajaran perkalian dasar dilakukan dengan memberikan masalah nyata yang diambil dari cerita yang dekat dengan konteks kehidupan siswa (contextual problem) sehingga siswa mengonstruksi konsep perkalian sendiri di kepalanya.

Jika pembelajaran perkalian dilakukan secara langsung pada tahap formal, dimana dalam kegiatan pembelajaran guru langsung menjelaskan konsep secara informatif, memberikan contoh soal, kemudian memberikan soal-soal latihan. Armanto (dalam Herman, 2006) menyebutkan kegiatan pembelajaran yang seperti ini tidak mengakomodasi pengembangan kemampuan siswa dalam pemecahan masalah, penalaran, koneksi, dan komunikasi matematis. Akibatnya, kemampuan kognitif tingkat tinggi siswa sangat lemah karena kegiatan pembelajaran yang biasa dilakukan hanya mendorong siswa untuk berpikir pada tataran tingkat rendah (Herman, 2006). Setelah anak memahami konsep perkalian dasar dengan benar, 
raraban baru diperkenalkan kepada anak.

Dengan menggunakan raraban ada beberapa pola yang terungkap untuk dijadikan dasar perkalian lanjut, antara lain sebagai berikut:

a. Setiap bilangan jika dikalikan dengan nol, hasilnya akan nol. Contoh: $\quad 1 \times 0=0, \quad 2 \times 0=0, \quad$ dan seterusnya.

b. Dengan melihat raraban 1 didapat, Setiap bilangan jika dikalikan satu hasilnya adalah bilangan itu sendiri (unsur identitas). 1×2=2, 1x5=5, dan seterusnya.

c. Dengan melihat raraban 2 didapat:

1) Setiap bilangan ganjil atau genap jika dikalikan dengan 2 , hasilnya adalah bilangan genap. Sehingga perkalian 2 dapat digunakan menggenapkan bilangan.

2) Istilah penggandaan, seperti dua kali lipat.

d. Dengan melihat dua raraban, seperti raraban 3 dan 4 $4 \times 3=3 \times 4=12$, atau $3 \times 7=7 \times 3=21$ pada raraban 3 dan 7 . didapat pola: salah satu sifat dalam operasi perkalian yaitu sifat komutatif (pertukaran).

e. Dengan melihat raraban 5 didapat pola:

1) Setiap bilangan ganjil jika dikalikan 5 hasilnya adalah bilangan ganjil dan angka pada satuannya adalah 5 .

2) Setiap bilangan genap jika dikalikan 5 hasilnya adalah bilangan genap dan angka pada satuannya adalah 0 .

f. Dengan melihat hasil perkalian pada salah satu raraban, Misalnya pada raraban 5: $5 \times 5=2 \times 5+3 \times 5$ artinya sama dengan $25=10+15$. Dan setelah beberapa kali dicoba ternyata bisa dilakukan juga pada raraban lain $(8 \times 4=2 \times 4+6 \times 4$, atau $32=8+24)$. Dari situ didapat pola salah satu sifat dalam operasi perkalian yaitu sifat distributif (penyebaran)

g. Dengan melihat raraban 10 didapat pola:

1) perkalian dengan 10 menghasilkan bilangan itu sendiri dengan menuliskan satu angka nol dibelakangnya, seperti $3 \times 10=$ (tulis) 3 ditambahkan satu angka nol ditempat satuan jadi 30

2) Jika mengalikan bilangan puluhan dengan puluhan seperti 10, 20, 30, dan seterusnya tinggal mengalikan bilangan yang paling depan (yang menempati puluhan), hasilnya adalah hasil perkalian itu kemudian ditambahkan dua angka nol dibelakangya. Atau dengan cara melihat hasil perkalian pada raraban Seperti: $10 \times 10=1 \times 1=1$ kemudian tulis dua nol dibelakangnya jadi 100, $20 \times 40=2 \times 4=8$ ditambahkan dua nol dibelakangnya jadi 800.

\section{Pola buku teks BSE (Buku Sekolah Elektronik)}

Dalam pola ini prosedur perkalian yang dihasilkan dari perilaku meniru atau mengulang materi yang terakhir dipelajari dari buku teks. Cara berfikir seperti itu disebut Piaget sebagai proses atau cara berfikir figuratif dimana pengetahuan yang didapatkan berasal dari hasil meniru atau mengulang materi yang terakhir dipelajari (Soeparno, 2001). i: 


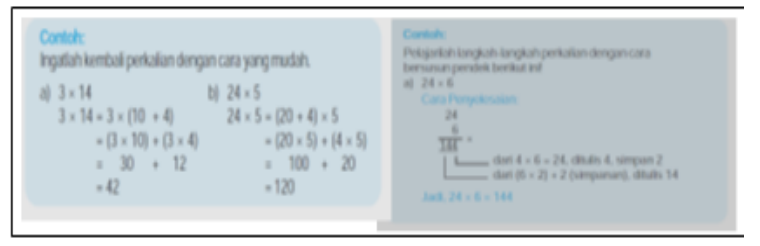

Gambar 5. Cara Perkalian Satu Digit dengan Dua Digit BSE

Untuk menjembatani anak masuk ke pola yang ada dalam buku BSE, guru dapat menggunakan pola pemodelan benda konkret, pola pemodelan dengan gambar, pola penjumlahan bersusun panjang dan pola raraban sehingga anak dapat memahami konsep dan berbagai sifat dalam operasi perkalian seperti sifat komutatif, sifat asosiatif, sifat distributif, unsur identitas, perkalian dengan 10, perkalian dengan nol, dan sebagainya. Selain itu, fakta-fakta penjumlahan dan nilai tempat lebih diperluas dengan penjumlahan lebih dari dua digit.

Pola-pola yang dipaparkan diatas dapat digunakan dan dimanfaatkan guru untuk menjembatani anak menuju konsep perkalian atau konsep matematika lainnya seperti konsep geometri dimana dalam mencari luas, keliling atau volume. Wahyudin (2011) menyebutkan bahwa apabila siswa mampu mengkaitkan ide-ide matematika maka pemahaman matematikanya akan semakin dalam dan bertahan lama karena mereka mampu melihat keterkaitan antar topik dalam matematika, dengan konteks selain matematika, dan dengan pengalaman hidup sehari-hari. Dengan kemampuan koneksi matematik, selain memahami manfaat matematika, siswa mampu memandang bahwa topik-topik matematika saling berkaitan (kemampuan koneksi matematis).
Untuk memperoleh kemampuan mengaitkan antar konsep, antar relasi konsep, dan antara pengetahuan konseptual dengan pengetahuan prosedural, guru perlu melatih siswa untuk mengaitkan model-model dengan simbol/ aturan/ prosedur. Untuk mengaitkan model (sebagai representasi dari konsep) dan simbol/aturan/ prosedur masih diperlukan kata-kata (Utomo, 2010). Jadi, dalam pembelajaran perkalian, melatih siswa untuk mengkoneksikan model, simbol/aturan/prosedur dan kata-kata adalah upaya untuk memperkuat basis pada kemampuan pemecahan masalah. Berikut ini adalah contoh bagaimana mengkoneksikan model dengan simbol, simbol dengan kata-kata, dan kata-kata dengan model dalam pembelajaran perkalian.

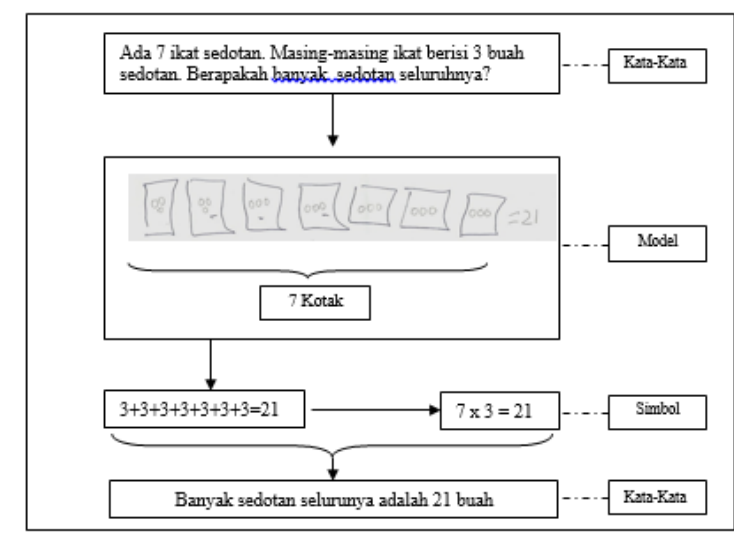

Gambar 6. Koneksi : Kata-Kata - Model - Simbol - Kata-Kata

Strategi-strategi atau cara-cara siswa tersebut merupakan salah satu tahap dari learning trajectory. Strategi atau cara para siswa menuju situasi belajar dan penalaran mereka sangat variatif. M. Suzanne Donovan dan John D. Bransford (2005) dalam bukunya How Students Learn History, Mathematics, and Science InThe Classroom menggambarkan ada berbagai alur atau proses berpikir anak yang 
berbeda dalam memahami matematika. Anak-anak secara jelas sangat bervariasi dalam pengembangan mental berhitung. Sangat mungkin memperkenalkan mereka ke berbagai representasi yang akan membantu mengembangkan kelebihan mereka dan mengakomodir keterbatasan mereka. Setiap siswa telah memperoleh tingkat pencapaian mereka saat ini melalui rute yang berbeda-beda dalam membangun kecakapan yang mereka miliki, sikapsikap yang mereka tanamkan, serta mode-mode berpikir yang mereka jadikan sandaran. (Wahyudin, 2010:21).

Aktivitas-aktivitas yang tidak membatasi jalan keberhasilan siswa pada satu rute saja merupakan kunci untuk merencanakan pengalamanpengalaman belajar yang merangsang berpikir siswa. (Wahyudin, 2010). Julie Sarama dan Douglas $H$. Clements (2009) menegaskan bahwa "Understanding the level of thinking of the class and individuals in that class is key inserving the needs of all children". Memahami tingkatan berpikir anak di kelas merupakan kunci dalam melayani kebutuhan semua anak. Pembelajaran yang efektif menuntut guru untuk memenuhi kebutuhan siswa dan membantu membangun pengetahuan yang diketahui siswa. Jadi, guru sebaiknya memahamilearning trajectories, cara anak berfikir dan belajar matematika, serta bagaimana membantu anak belajar lebih baik.Pentingnya alur belajardapat dianalogikan dengan perencanaan rute perjalanan. Jika kita memahami rute-rute yang mungkin untuk menuju tujuan kita maka kita bisa memilih rute yang baik. Selain itu, kita juga bisa menyelesaikan permasalahan yang kita hadapi dalam perjalanan jika kita paham rute tersebut. Sebagai contoh adalah kita bisa mengantisipasi kehabisan bahan bakar jika kita tahu posisi pom bensin. Sedangkan pengembangan model sangat penting untuk membawa pengetahuan informal siswa (modal awal siswa yang terbentuk melalui kegiatan berbasis pengalaman) menuju konsep matematika formal (sebagai tujuan akhir pembelajaran matematika).

\section{SIMPULAN}

Ketika siswa belajar perkalian baik perkalian dasar maupun perkalian lanjut, mereka mengikuti suatu pola tingkatan alamiah, yakni belajar kemampuankemampuan dan ide-ide perkalian dengan cara mereka sendiri. Keragaman pola empirical learning trajectory perkalian yang terungkap secara umum sebagai berikut:

1. Pada perkalian bilangan satu digit ada empat pola yang terungkap yaitu:

a. Pola 1: Pemodelan dengan benda konkret, Dari model benda konkret tersebut ada tiga tahap yang dilakukan siswa yaitu:
1) Siswa
menggabung- gabungkan benda konkret

2) Membilang satu-satu melibatkan aktivitas membilang menaik dimulai dari satu sampai bilangan terakhir yang diucapkan. Hasil dari pola ini adalah pembilangan terakhir yang diucapkan merupakan jumlah dari semua bilangan yang dibilang.

3) Siswa menulis lambang bilangan dan operasi penjumlahan, kemudian menjumlahkan bilanganbilangan tersebut secara beruntun sampai diketahui jumlah seluruhnya. 
b. Pola 2: Pemodelan dengan gambar, dimana pada tahap ini siswa sudah mampu mengandaikan bahwa sebuah gambar dapat mewakili benda konkret. Dari model gambar tersebut ada empat tahap yang dilakukan siswa yaitu:

1) Siswa membuat pemodelan menjadi sebuah gambar

2) Siswa membilang satu-satu sampai diketahui banyak benda yang ada pada gambar seluruhnya.

3) Siswa membuat garis bilangan dengan angka nol sebagai titik awal.kemudian membilang loncat dua-dua atau tiga-tiga (tergantung gambar) sampai pada bilangan loncatan terakhir sebagai jawaban banyak benda seluruhnya.

4) Siswa menulis lambang bilangan dan operasi penjumlahan, menjumlahkan kemudian bilanganbilangan tersebut secara beruntun sampai diketahui jumlah seluruhnya. c. Pola 3: Penjumlahan, dimana pada pola ini terdiri atas aktivitas menjumlahkan bilangan yang sama secara bersusun sampai diperoleh bilangan baru sebagai hasil dari penjumlahan bilangan seluruhnya.

d. Pola raraban, yaituhapalan perkalian dasar.

2. Pada perkalian bilangan multi digit ada dua pola yang terungkap yaitu:

a. Pola Penjumlahan Bersusun Panjang, dimana pada Pola ini terdiri atas aktivitas menjumlahkan bilangan yang sama secara bersusun panjang kebawah sampai diperoleh bilangan baru sebagai hasil dari penjumlahan bilangan seluruhnya. Untuk mengatasi hal ini, selanjutnya siswa diarahkan untuk mencari cara lain yang lebih singkat/pendek dengan menggunakan sifat-sifat perkalian.

Pola Buku Teks BSE, dimana pada pola ini terdiri dari aktivitas mengalikan satu bilangan dengan dua bilangan atau lebih dengan cara bersusun panjang atau bersusun pendek.

\section{DAFTAR PUSTAKA}

BobPerry and SueDockett. (2007). Early Childhood Mathematics Education Research: What is Needed Now?. Australia: Mathematics Education Research Group of Australasia.

Clements and Sarama. (2009). Learning Trajectories in Early Mathematics - Sequences of Acquisition and Teaching. Canada: Canadian Language \& Research Network

Dahar, R.W. (2006). Teori-Teori Belajar dan Pembelajaran. Jakarta: Erlangga.

Departemen Pendidikan Nasional. (2006). LampiranPermendiknas Nomor22 Tahun 2006 Tentang Standar Isi untuk Satuan
Pendidikan Dasar. Jakarta: Depdiknas.

Denzin, N.K,.and Lincoln Y. S. (2009). Handbook of Qualitative Research. Yogyakarta: Pustaka Pelajar.

Donovan, M. S dan John D. B (Eds). (2005). How students learn: history, mathematics, and science in the classroom. Washington, D. C: The National Academies Press

Fajariyah, $\mathrm{N}$ dan Triratnawati, $\mathrm{D}$. (2008). Cerdas Berhitung Matematika untuk SD/MI Kelas 3. Jakarta: Pusat Perbukuan Depdiknas

Freudenthal, H. (1991). Revisiting Mathematics Education: China 
Lectures. Dordrecht, The Netherlands: Kluwer Academics Publisher.

Gravemeijer, K. (2004). "Local Instruction Theories as Means of Support for Teachers in Reform Mathematics Education". Mathematical Thinking and Learning, 6(2), 105-128.

Haryanto, ( $)$. Teori yang Melandasi Pembelajaran

Konstruktivistik. [online]. Tersedia: http://staff.uny.ac.id/sites/default/fi les/131656343/TEORI\%20KONS TRUKTIVISTIK.pdf [07/08/2012].

Harahap, F. (_). Perkembangan Kognitif Teori Piaget. [online]. Tersedia:

http://staff.uny.ac.id/sites/default/fi les/pendidikan/Nanang\%20Erma \%20Gunawan,\%20S.Pd./Teori\%2 Operkembangan\%20Kognitif\%20P iaget\%201.pdf [07/08/2012].

Herman, T. (1999). "Mengajarkan Konsep Prabilangan di Sekolah Dasar". Makalah disajikan dalam Penyuluhan dan Diskusi Pembelajaran Matematika SD dan SLTP di Kecamatan Tarogong Kabupaten Garut Pada Tanggal 14 Agustus 1999.

Herman, T. (_ _ ). "Matematika dan Pembelajaran Matematika di SD dan SLTP: Suatu Refleksi Menyeluruh". Artikel dipublikasikan dalam Repository Dosen Jurusan Pendidikan Matematika FPMIPA Universitas Pendidikan Indonesia.

Heruman, (2007). Model

Pembelajaran Matematika di Sekolah Dasar. Bandung: PT. Remaja Rosdakarya.

Holt, J. (2012). Bagaimana Siswa Belajar. Jakarta: Erlangga

Hudoyo, H. (1990). Strategi Mengajar Belajar Matematika. Malang: IKIP Malang.
Hunting, R.P (1997). Clinical Interview Methods in Mathematics Education Research and Practice . Journal of Mathematical Behavior, 16(2), 145-165.

Morrisson, G.S. (2012). Dasar-Dasar Pendidikan Anak Usia Dini (PAUD) "Edisi Kelima". Jakarta: PT. Indeks

Mousley, J. Et all.(2004). "Alternative Learning Trajectory". Mathematics Education Research Group of Australasia. Conference (27th: 2004: Townsville, Qld.), 374-381.

Mousley, J. Et all.(2009).Tasks and Pedagogies that Facilitate Mathematical Problem Solving. Association of Mathematics Educators-National Institute of Education, Singapore. (p.15-48).

Mustoha, A dkk. (2008). Senang Matematika 2 Untuk SD/MI Kelas 2. Jakarta: Pusat Perbukuan Depdiknas

Nurdin. (2011). "Trajectory dalam Pembelajaran

Matematika". Edumatica. 01. (01), 1-7

Prabawanto, S. (2003). Konstruktivisme dalam Pembelajaran Matematika di Kelas Satu dan Dua Sekolah Dasar. "Makalah Disampaikan dalam Rangka Kegiatan Magang Dosen IKIP PGRI SEMARANG Pada Program D-2 PGSD FIP UPI 20 - 27 Maret 2003". Bandung: UPI

Putri, R.R.E .(2010). Pengaruh Permainan Congklak terhadap Kemampuan Membilang Anak TK. Skripsi pada Prodi PAUD UPI. Bandung: UPI.

Raharjo, M dkk.(2009). Pembelajaran Operasi Hitung Perkalian dan Pembagian Bilangan Cacah di SD. P4TK Matematika Departemen Pendidikan Nasional. 
Risnanosanti. (2010). Kemampuan Berpikir Kreatif Matematis dan Self Efficacy Terhadap Matematika Siswa Sekolah Menengah Atas (SMA) dalam Pembelajaran Inkuiri. Disertasi pada Prodi Pendidikan Matematika UPI. Bandung: UPI.

Robert C.P Et. all. (2008). Classroom Effects on Children's Achievement Trajectories in Elementary School. Australia: MERGA.

Salimi, M. (2010). Model Enactive, Iconic dan Simbolic untuk meningkatkan pemahaman konsep perkalian siswa kelas II SDN Pancasila Kabupaten Bandung Barat. Skripsi pada Prodi PGSD UPI. Bandung: UPI.

Santrock, John W. (2007). Perkembangan Anak Jilid 1 (Terjemahan). Jakarta: Erlangga.

Sarama and Clements. (2009). Early Childhood Mathematics Education Research :Learning Trajectories for Young Children. New York: Routledge.

Sarama and Clements. (2009). Learning and Teaching Early Math : The Learning Trajectories Approach. New York: Routledge.

Simon, M. A. (1995). Reconstructing Mathematics Pedagogy from a ConstructivistPerspective. Journal for Research in Mathematics Education, 26(2), 114-145.

Stephens, M dan Armanto,D. (2010). How to Build Powerful Learning Trajectories for Relational Thinking in the Primary School Years. Australia: Mathematics Education Research Group of Australasia

Sugiyono. (2012). Memahami Penelitian Kualitatif. Alfabeta.

Suparno, P. (2001). Teori Perkembangan Kognitif Jean Piaget. Jogjakarta: Kanisius.
Suryadi, D. (2011). Didactical Design Research (DDR) Dalam Pengembangan Pembelajaran Matematika.Makalah disajikan pada Joint-Conference UPIUTiM, 25 April 2011. Bandung: UPI

Taylor, E.H. and Mills, C.N. (1961). Arithmetic for Teacher-Training Classes. New York: Holt, Rinehart and Winston, Inc.

Thompson, I. (2000). "Teaching Place Value in the UK:time for a reappraisal?". Educational Review. 52. (3), 291-298.

UPI. (2011). Pedoman Penulisan Karya IImian UPI. Bandung: UPI.

Utomo, P.D. (2010). "Pengetahuan Konseptual dan Prosedural dalam Pembelajaran Matematika". Makalah disampaikan pada Seminar Nasional Matematika dan Pendidikan Matematika UniversitasMuhammadiyah Malang tanggal 30 Januari 2010.

Wahyudin. (2010). MateriPembelajaran Matematika Kelas Rendah. Bandung: Penerbit Mandiri.

Wahyudin. (2011). MateriPembelajaran Matematika Kelas Tinggi. Bandung: Penerbit Mandiri.

Wahyudin. (2012). Filsafat dan ModelModel Pembelajaran Matematika. Bandung: Penerbit Mandiri.

Zuhri, D. (1998). Proses Berpikir siswa Kelas II SMPN 16 Pekanbaru dalam Menyelesaikan Soal-Soal Perbandingan Senilai dan Perbandingan Berbalik Nilai. TesisMagister pada Program Pascasarjana UNESASurabaya:Tidak diterbitkan 
